\title{
小児の遊戯中に発生した口蓋刺創症例
}

\author{
北村 裕*.古田 勲*・小浜源郁* ・上 野 正* - 水野明夫**
}

\section{Stick wound of the palate of children on playing.}

\author{
Hiroshi Kitamura* • Isao Furuta* • Gen-iku Kohama* \\ Tadashi UENo* - Akio Mizuno**
}

\section{腥言}

小児の口蓋部外傷は上顎骨骨折飞合併するるの4) を除 き，単独の外傷に関する報告は少なく，著者の涵狪しえ た限りでは Crowford $\left.{ }^{2}\right)(1970)$ が過去10年間に経験した 12例を報告しているのみである. われわれは最近 5 年間 に，小児の遊戯中に発生した口蓋刺創 9 例を経験し，興 味ある知見を得たので報告する。

\section{症}

\section{例}

経験症例 9 例のらち男児 4 例，女児 5 例，受傷時年龄 は7カ月から 5 歳にわたっている。これらの症例は，い ずれる風車の棒や竹棒などを口にくわ文遊戯中転倒した 際に，これらの棒がロ蓋部につき刺さク，同部軟組織の 刺創を起こしており, 全例において事故原因, 受傷部位, 創倁の型などに近似性が認められた（表 1，図 1)。そ の処置としては, 縫合 7 例, 創洗浄のみ 2 例で, 予後は 全例とす良好であった．次にこれら9症例の代表例とし て症例 1 おび症例 9 Kついて述べる.

症例 1

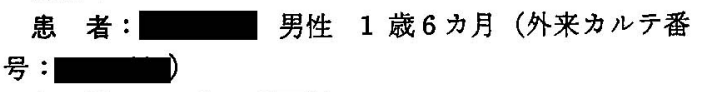

初 診：1971年10月曰日

主 訴：口蓋部穿孔

現病麻：1971年10月口日, 午後 8 時頃, 特もちゃの風 車の棒を口腔内にくわえたまま転倒した、その時, 口腔 および鼻腔からの出血，ならびに口蓋部に裂創がみられ

* 東京医科歯科大学齿学部第一口腔外科学教室 （主任：上野 正教授）

** 岩手医科大学齿学部第二口腔外科学教室 (主任：䦎山三郎数授)

* First Department of Oral Surgery, School of Dentistry, Tokyo Medical and Dental University (Chief : Prof. Tadashi Ueno)

** Second Department of Oral Surgery, School of Dentistry, Iwate Medical University

(Chief : Prof. Saburo Sekiyama)

受付 : 昭和 51 年 3 月 23 日
たため，外科医院を受診し，同院より当科を紹介され， 翌日，当科を受診した。

現 症：硬口蓋中央からやや右側よりに $30 \mathrm{~mm} \times 10$ $\mathrm{mm}$ 大の粘膜裂㓣ならびに骨の露出が存在したが䀠䧑 への穿孔は認められなかった。

処置および経過：初診時に本学歯科麻醉科外来にて経 鼻吹込法によるG. O.F. 全身麻醉下のもとに口盖損管 部の綟系縫合術を行い, 術後は感染防止の目的で抗生剂 を 5 日間投与した。術後経過は良好であった（写真 1， $2,3)$.

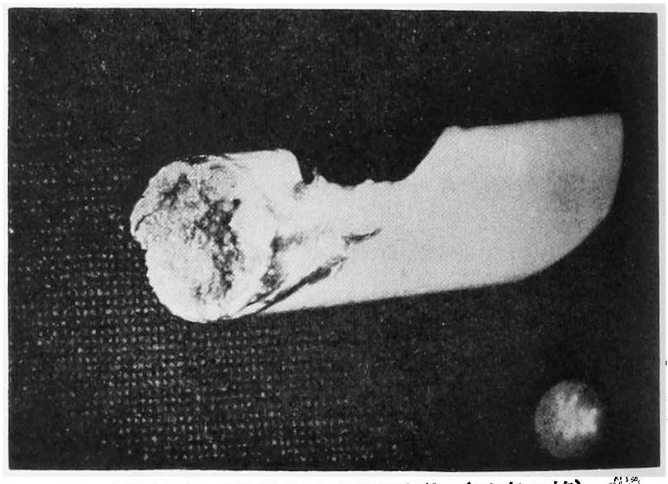

写真 1 症例 1 の原因物体（風車の棒）

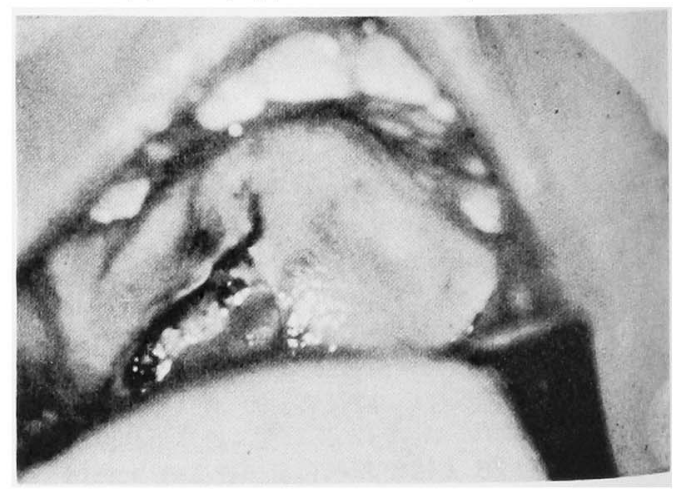

写真 2 症例 1 の初診時 
表 19 症例の臨床所見

\begin{tabular}{|c|c|c|c|c|c|c|c|c|}
\hline 症 & 例 & 性別 & 年 令 & 受侔 日 & 原 因 物 体 & 受 & $\begin{array}{l}\text { 創き } \\
\text { 大き }\end{array}$ & 処置日，処置法 \\
\hline 1. & & 男 & $\begin{array}{l}1 \text { 才 } 6 \\
\text { カ月 }\end{array}$ & 71.10. & 風車の棒 & 硬 只蓋な 中 央 & $\begin{array}{l}30 \times 10 \\
\quad(\mathrm{~mm})\end{array}$ & $\stackrel{2 \text { 日目 }}{\text { 全身麻䣲て縫合 }}$ \\
\hline 2. & & 女 & 4 才 & 73. 4 . & 物 差 し & 左 硬孔口し蓋 & $\begin{array}{l}10 \times 5 \\
(\mathrm{~mm})\end{array}$ & $\begin{array}{c}2 \text { 日目 } \\
\text { 創 洗 湺 }\end{array}$ \\
\hline 3. & & 女 & 5 才 & 73. 10 . & 竹の細い棒 & $\begin{array}{c}\text { 硬軟口蓋な移行部 } \\
\text { 穿孔なし }\end{array}$ & $\begin{array}{r}10 \times 5 \times 5 \\
(\mathrm{~mm})\end{array}$ & $\begin{array}{c}\text { 6日目 } \\
\text { 局所麻酔で䋖合 }\end{array}$ \\
\hline 4. & & 男 & 7 力月 & 74. & スプーン & 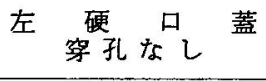 & 小指頭大 & $\begin{array}{c}2 \text { 日目 } \\
\text { 局所麻酔で䋖合 }\end{array}$ \\
\hline 5. & & 女 & $\begin{array}{l}1 \text { 才 } 3 \\
\text { カ月 }\end{array}$ & 74. 4. & 竹 & 右 軟 口蓋 & 拇指頭大 & $\underset{\text { 全身麻酔で縫合 }}{2 \text { 日 }}$ \\
\hline 6. & & 男 & $\begin{array}{l}1 \text { 才10 } \\
\text { 力月 }\end{array}$ & 75. & 鉄裂タオル掛け & $\begin{array}{c}\text { 軟 蓋む 中 央 } \\
\text { 穿孔㐌 }\end{array}$ & $\begin{array}{l}8 \times 3 \\
(\mathrm{~mm})\end{array}$ & $\begin{array}{c}3 \text { 日目 } \\
\text { 全身麻醉で絴合 }\end{array}$ \\
\hline 7. & & 女 & $3 才$ & 75. 2 . & 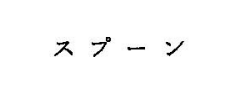 & 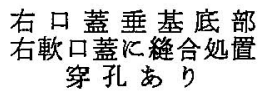 & 小豆大 & 経過観察中 \\
\hline 8. & & 女 & $2 才$ & 75. 4. & 竹 & 左 硬 口な 蓋 & $\frac{17 \times 10}{(\mathrm{~mm})}$ & $\begin{array}{c}2 \text { 日目 } \\
\text { 全身麻酔で縫合 }\end{array}$ \\
\hline 9. & & 男 & $\begin{array}{l}4 \text { 才 } 7 \\
\text { カ月 }\end{array}$ & 75. 5 . & 玩具の鯉上りの棒 & 左 軟孔口蓋 & 10(mm) & 局所麻酔で綘合 \\
\hline
\end{tabular}

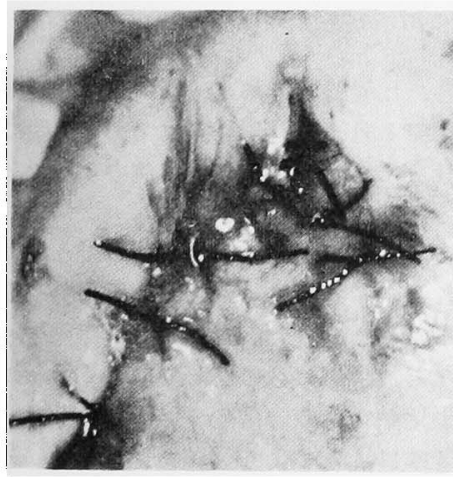

写真 3 症例 1 の手術直後

\section{症例 9}

患者: 男性 4 歳 7 カ月（外来カルテ番 号:

初 診: 1975年 5 月日日

主 訴: 口腔内刺創

現病歴：1975年 5 月曰日，午前11時半頃，自宅の鏡台 （高さ約 $1 \mathrm{~m}$ ）より觟上りの竹棒を口にくわえたまま飛 び降りた際，军に竹棒の先が当り，その反動で口にくわ えていた竹棒の先端が左軟口蓋部につき刺さり，同部の 刺侮を受け，直ちに救急車にて某病院を受診したが特に 処置を受けす，同院より当科を紹介され来院した。

現 症 : 左側軟口蓋の煩側よりに鼻腔穿孔を伴う径

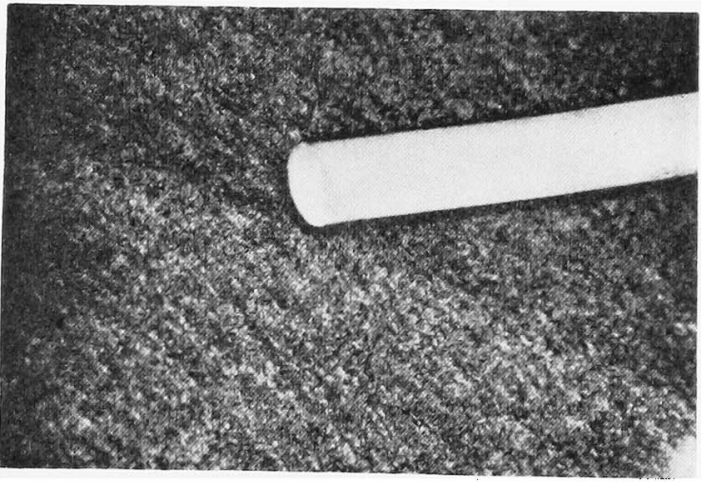

写真 4 症例 9 の原因物体（玩具の棒）

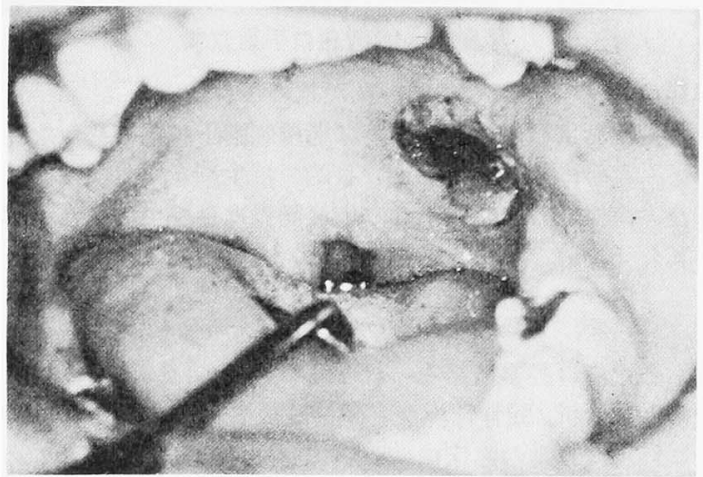

写真 5 症例 9 の初診時 

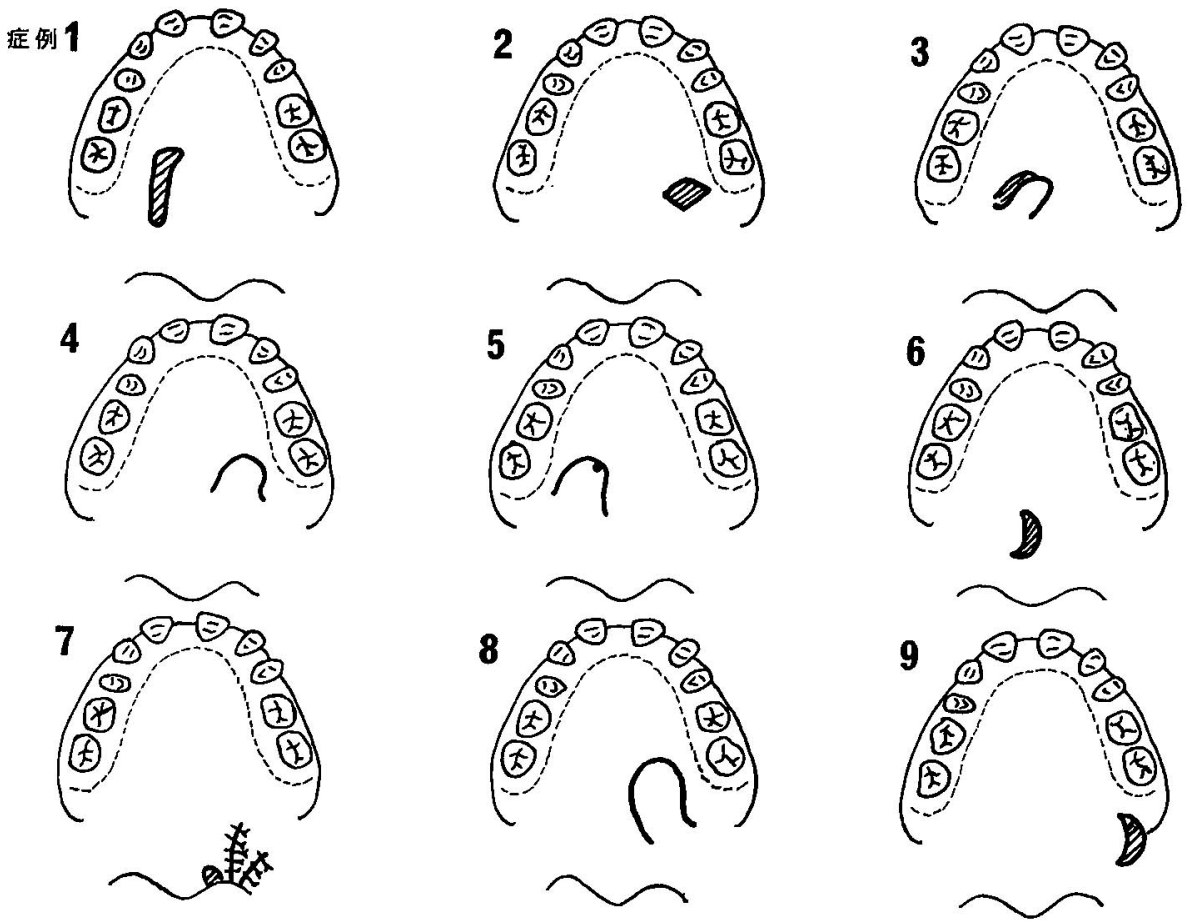

図 1 受稘 部 位

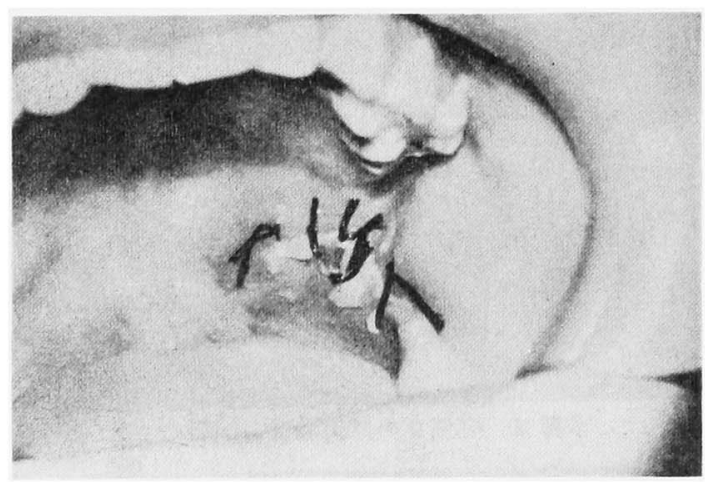

写真 6 症例 9 の手術直後

$15 \mathrm{~mm}$ の半月状の弁状裂創が認められた.

処置および経過：初診時に局所麻醉下に綟系縫合を行 い,ささらに術後感染防止の目的で抗生剤を 4 日間投与し た. 術後 7 日目に拔系し，術後経過は良好であった（写 真4, 5, 6).

考察

小児の口腔領域にみられる外傷としては，歯牙外傷，

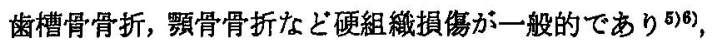
これらは日常の臨床ににおいてしぱしば経験されるすの である、一方, 硬軟口蓋部単独の外傷怯, 頻骨骨折に合
併するものを除くと，比較的稀である．当科泫ける本 症例をみると，1972年 1 月より 74年12月までの 3 年間保 受診した小児 (15歳まで) の外傷患者 123 例中 4 例で， その割合は $3.3 \%$ の低頻度を示している.

本 9 症例について詳細倹討した結果，次のよ5な臨 床的特徵が認められた，すなわち，その事故原因をみる と, 原因物体は風車の棒, 物差し, 竹の棒, スプーン, 竹笛，タオル掛けなど，小児の身のまわりによく見られ るもので，乙かも小児が口にくわえやすい形態のすので あった．本症例患者は口にこのような異物をくわえ，遊 戲中，独りで枟倒したり，後から押されて，くわえた器 物が前方の壁などに当って受傷しており，その受侮部位 は硬口蓋 4 例，軟口蓋 4 例，硬軟口蓋移行部が 1 例であ った.

奥腔への穿孔は 9 例中 4 例飞認められた。 また，出血 に関しては時として大口蓋動脈を損傷し大出血をきたす ことがあるといわれるが22，本症例群では同創より自然 止血しえなかったはどの多量の出血は経験されなかっ た。

処膡については，われわれは比較的小範团の裂創であ れば感染予防処置のみで外科的処㯰を行かないか，裂創 縁が㔀離して弁状に下垂し，骨面が露出している湯合， あるいは明らかな腔呀孔の認められるるのは，早期飞 外科的処膡を行らことを原則としており，本症例群で 
受傷後 3 日以内の新鮮例においては初診時に释合処置を 行い, 6 日目の 1 例のみ新創面を作り縫合を行った. Crowford はたとえ穿孔があっても大口蓋動脈を損傷し ていなければ, あえて外科的療法を行ら必要はないと記 載している，他方，大谷ら゙〉は分婏時に傷害を受け，言 語障害を後遗した症例を報告している。

$$
\text { ま と め }
$$

われわれは 7 カ月から 5 葴までの小児が遊歔中, 口に 器物をくわえ, 口蓋に特有の刺傷を受けた 9 例を経験し たのでその治験を報告した。
文献

1）上野 正, 他: 顏面外伤. 医学書院, 東京, 1970, 245頁.

2) Crowford, B. S. : The management of perforating wounds of the palate. Brit J Plast Surg $23: 2621970$.

3）大谷隆俊, 国清泰男: 言語障害を伴った軟口蓋裂 傷の一例. 口科誌 $17: 1801968$.

4）清水正侷: 口蓋の穿孔性外伤. 歯科時報 $26: 18$ 1972.

5）小浜源郁，清田健司：歯槽骨骨折ならびに歯牙外 賃の診断と治療. 歯科時報 $28: 161974$.

6）清水正咟：小児の買骨骨折. 日本歯科評論 348 : 13251971.

7) Berényi, B. : Unfallkieferchirurgie im Kindesalter. Dtsch Stomat $15: 2901965$. 